\title{
Reclaiming Our Democracy: The Way Forward
}

\author{
JOHN MCCAIN
}

A FTER SEVEN YEARS of legislation and litigation and, finally, a landmark decision by the United States Supreme Court, those of us who care about campaign finance reform find ourselves at a unique moment of opportunity.

Now that the dust has settled, it has become clear that a majority of the Justices did much more in McConnell v. FEC ${ }^{1}$ than uphold the Bipartisan Campaign Reform Act of 2002 (BCRA). The Court saw the same stark dangers the law's congressional supporters perceived in the flood of unlimited cash payments by corporations, labor unions and wealthy individuals that was washing through the offices of party leaders and elected officials in Washington. The justices recognized that the widespread use of corporate and labor funds for political advertising featuring federal candidates in the midst of campaigns made a mockery of the longstanding ban on the use of these funds in federal elections. And, most critically, the Court recognized that these practices have gravely diminished public confidence in the honest functioning of our democratic system of government. These holdings, and the Court's clear rationale for its conclusions, supply the principles that will serve as a roadmap for the next steps in our fight to reclaim this nation's democracy for all of its citizens.

The goal of BCRA was simple and straightforward: to break the corrupting relationship

John McCain is the senior United States Senator from Arizona. He was a principal sponsor of the Bipartisan Campaign Reform Act of 2002 and an intervenor-defendant in McConnell $v$. FEC. The author gratefully acknowledges the assistance of Mark Glaze of the Campaign Legal Center and the Reform Institute in the preparation of this article. that had developed through campaign contributions between corporate and labor special interests and the wealthiest individuals, on the one hand, and the government officials who make public policy on the other. But even that important step is in the service of a more fundamental purpose: to restore the American people's faith that their government belongs to them, and not only to those who can afford enormous payments to parties and candidates. That faith, badly damaged these past years, is the indispensable element of a working democracy. Without it, citizens' incentive to participate in the civic life of their own nation will shrink to the vanishing point. And no democracy can live with that loss.

Now that we have crossed the initial threshold of passing a campaign finance reform law that the Supreme Court has firmly upheld, we need to do much more to return political power to ordinary citizens. To do that, we must work toward a system of campaign finance law in which the incentives favor real candidate competition and real engagement with the American people. And those laws must be fully and fairly enforced. The principles in McConnell $v$. $F E C$ set the predicate for these necessary next steps.

\section{LARGE POLITICAL CONTRIBUTIONS CAUSE BOTH THE APPEARANCE AND REALITY OF PUBLIC CORRUPTION}

At its core, the fight for BCRA was an effort to achieve a definitive legal statement of the patently obvious: large political contributions

\footnotetext{
1124 S. Ct. 619 (2003).
} 
buy access to, and influence with, the people who make public policy. To even the most casual student of human nature, politics or history, the notion that officeholders and candidates-with their near-constant need to raise the large sums necessary to run an effective campaign-will tend to reward those who give the most money seems remarkably like common sense. And the notion that the political parties-which exist solely to elect those officials, and which deploy those officials to raise their funds-will see to it that party donors are granted special access to policymakers seems equally hard to deny.

For seven years, however, opponents of campaign finance reform put themselves in the position of arguing that the only real political corruption is the quid pro quo-the direct exchange of money for a specific vote or other official act. That claim, in turn, was necessarily based on the idea that a large political gift falling short of bribery does not buy an unfair benefit for the giver. $^{2}$

The Supreme Court decision definitively sweeps aside both of these arguments. Building on twenty-five years of precedent going back to Buckley v. Valeo, ${ }^{3}$ the majority in $\mathrm{Mc}$ Connell flatly rejected the notion that Congress has no power to address any form of corruption beyond actual bribery of public officials:

Our cases have made clear that the prevention of corruption or its appearance constitutes a sufficiently important interest to justify political contribution limits. We have not limited that interest to the elimination of cash-for-votes exchanges. In Buckley, we expressly rejected the argument that antibribery laws provided a less restrictive alternative to FECA's contribution limits, noting that such laws "deal[t] with only the most blatant and specific attempts of those with money to influence government action." . . . Thus, [i]n speaking of 'improper influence' and 'opportunities for abuse' in addition to 'quid pro quo arrangements,' we [have] recognized a concern not confined to bribery of public officials, but extending to the broader threat from politicians too com- pliant with the wishes of large contributors. ${ }^{4}$

The Justices went farther, however. The Court cut to the core of the issue, concisely describing the basic concern that has moved Congress, time after time, to pass new reforms in response to specific threats of corruption: the need to maintain the essential faith of the people in their elected officials and institutions. "Take away Congress' authority to regulate the appearance of undue influence," the majority warned, "and the cynical assumption that large donors call the tune could jeopardize the willingness of voters to take part in democratic governance." 5 Given polling data indicating that nearly three-quarters of the public believes that members of Congress sometimes act on behalf of big contributors to their political party regardless of whether their action is right for the country or what their constituents want, ${ }^{6}$ congressional willingness to address the problem has never been more vital.

The Justices also dismissed the absurd proposition that large political contributions serve no specific purpose for the contribu-

2 The same opponents put themselves in the equally absurd position of arguing that advertisements run days before a congressional election like the one transcribed below were not campaign ads, and could therefore be funded with soft money, because they avoided using words like "defeat" or "vote against:"

Who is Bill Yellowtail? He preaches family values, but he took a swing at his wife. And Yellowtail's response? He only slapped her. But 'her nose was broken.' He talks law and order . . . but is himself a convicted felon. And though he talks about protecting children, Yellowtail failed to make his own child support payments - then voted against child support enforcement. Call Bill Yellowtail. Tell him to support family values."

See U.S. Senate Committee on Governmental Affairs, Investigation of Illegal or Improper Activities in Connection with the 1996 Federal Election Campaigns, S. Rep. No. 105-167, at 6304-05 (1998).

${ }^{3}$ Buckley v. Valeo, 424 U.S. 1 (1976).

${ }^{4}$ McConnell v. FEC, 124 S.Ct. 619, 660 (2003) (quotations and citations omitted).

${ }^{5} \mathrm{Id}$. at 660-61 (quotations and citations omitted).

${ }^{6}$ See Press Release, Democracy 21, "New Bipartisan Poll Finds Public Believes Big Contributions to Political Parties Have Detrimental Influence on System" (Sept. 24, 2002), available at www.democracy21.org. 
tor-that, as the argument goes, money merrily follows ideology, rather than buying rewards. Drawing on thousands of pages of affidavits from politicians, corporate officials and political scientists, and the decision of the three-judge trial court, the Court flatly concluded that soft money contributions were designed to, and did, purchase influence over public policy. The evidence conclusively linked corporate, union and individual donations to the parties to "manipulations of the legislative calendar, leading to Congress' failure to enact, among other things, generic drug legislation, tort reform, and tobacco legislation," the majority wrote. ${ }^{7}$ Full pages of the decision are given over to the Court's description of the record evidence documenting the fact that the national party committees were in the business of "peddling access to federal candidates and officeholders in exchange for large soft-money donations." 8 That phenomenon, the Justices affirmed, is just as surely a form of public corruption as the outright sale of votes.

Indeed, the insistence that there was nothing untoward about exchanging huge corporate contributions for special influence on public policy is but one example of a Washington political culture in which such exchanges are commonplace. In an astonishing display of the degree to which this way of doing business has become institutionalized, consider the little-known fact that the Clinton Administration's Justice Department, responding to queries relating to the fundraising scandals of the 1996 presidential election, released a lengthy letter setting forth the government's policy that the explicit sale of access to public officials is not illegal. ${ }^{9}$ This understanding was reiterated by the Department after Attorney General John Ashcroft took office. ${ }^{10}$

The Court's decision should stand for more than the proposition that Congress can regulate to prevent corruption or its appearance. The broader principle that one of the main obligations of government is to act in a way that protects public faith in institutionswhether through direct regulation or carefully structured incentives-should guide our next steps in campaign finance reform.

\section{THE FEDERAL ELECTION COMMISSION WAS LARGELY RESPONSIBLE FOR CREATING THE SOFT MONEY CRISIS}

Perhaps the most striking aspect of the decision is how directly the Court laid the blame for the development of the party committees' influence peddling schemes squarely at the door of the Federal Election Commission. The soft money phenomenon was entirely the result of a series of loopholes written into the law by the very agency charged with its enforcement, and the eagerness of the party committees to extend these loopholes.

The Commission put campaign law on the path to oblivion a generation ago, although the full effects did not become apparent for several years. As the Court explained, Congress had banned corporate and union participation in federal elections in 1907 and 1947. Beginning in 1978, however, the agency issued a series of rules that allowed the national and state parties to use "soft money" funds for activities that directly influenced federal elections, along with state elections. Over the years, creative party committee officials developed a voracious appetite for these funds, using them to finance sham "issue ads" promoting or attacking federal candidates and other federal electioneering activity. ${ }^{11}$

Though reform opponents portrayed BCRA as massive new regulation of political speech, the new law was actually, in the Court's words, a "modest"12 attempt to return campaign finance law to where it had been, prior to the FEC's tampering. In particular, the law's prohibition on soft money solicitation and spending by the national parties "simply effects a re-

\footnotetext{
${ }^{7}$ McConnell, 124 S.Ct. at 664.

${ }^{8} \mathrm{Id}$.

${ }^{9}$ Letter from Attorney General Janet Reno to U.S. Rep. Henry Hyde, Oct. 3, 1997.

${ }^{10}$ Letter from Lee Radek, Chief of the U.S. Department of Justice Public Integrity Division, to Larry Klayman, Judicial Watch, July 30, 2001.

${ }^{11}$ For a complete and authoritative history of the soft money phenomenon, see Anthony Corrado, Party Soft Money, in Campaign Finance Reform: A Sourcebook (Anthony Corrado, Thomas E. Mann, Daniel Ortiz, Trevor Potter \& Frank Sorauf eds., 1997).

${ }^{12}$ McConnell, 124 S.Ct. at 660.
} 
turn to the scheme that was approved in Buckley and that was subverted by the creation of the FEC's allocation regime, which permitted the political parties to fund federal electioneering efforts with a combination of hard and soft money."13 If there were any further doubt about where responsibility lay for soft money, the Court went farther:

The fact that the post-1990 explosion of soft-money spending on federal electioneering was accompanied by a series of efforts in Congress to clamp down on such uses of soft money (culminating, of course, in BCRA) underscores the fact that the FEC regulations permitted more than Congress, in enacting FECA, had ever intended. ${ }^{14}$

The lesson here-that the government's enforcement agency has been a main agent of the campaign finance law's unraveling-must also guide future legislative action.

\section{PROBLEMS IN THE CAMPAIGN FINANCE SYSTEM WILL RECUR, AND WHEN THEY DO, CONGRESS CAN AND SHOULD ACT TO FIX THEM}

Of all the arguments reform opponents regularly invoke, perhaps the most ludicrous is this: because there are incentives to evade reforms, and circumvention may occur, Congress shouldn't bother to pass reform laws in the first place. That charge simply ignores the well-documented history of campaign finance law over time.

Indeed, as the Court set forth in detail, the history of soft money over the past decade, which culminated in BCRA and McConnell $v$. $F E C$, is only the latest cycle in a pattern that has repeated itself throughout the last century. In this pattern, new political practices develop that cause public outrage over corruption, real and perceived, and Congress acts to stem that corruption-only to have the cycle repeat itself in the next generation. In the last part of the $19^{\text {th }}$ Century, progressive reformers and "muckraking" journalists objected to the nearcomplete domination of corporate and business money in national politics. Combined with allegations of financial impropriety in the 1904 presidential elections, public dismay led to the 1907 law banning corporations from using their general treasuries for political contributions, and the first disclosure laws in 1910 and 1925. Widespread concern about the growing influence of union contributions led to their prohibition in the Taft-Hartley Act in 1947. Again in the 1970s, renewed public concern over the influence of special interest money, culminating in the campaign finance abuses of the Watergate scandal, set the stage for the Federal Election Campaign Act of 1971 and its amendments in 1974. And a generation later, when the full scope of the soft money problem finally became apparent, Congress passed BCRA to address it. $^{15}$

In the final passage of the majority's opinion, the Court itself dismissed the notion that the inevitability of circumvention is an argument for abdication. "We are under no illusion," the Justices wrote, "that BCRA will be the last congressional statement on the matter. Money, like water, will always find an outlet. What problems will arise, and how Congress will respond, are concerns for another day."16

What Congress did in BCRA is, of course, no guarantee that we will not need to travel the road of wholesale reform again in a generation, and perhaps in fewer years than that. I believe, however, that Congress can act now to make the new law work, and push forward with other important reforms, rather than waiting until the cycle of crisis repeats itself. Drawing on the lessons contained in the Court's decision, we can move on several fronts to make our democracy better, and reduce barriers to political participation.

\section{- Replace the Federal Election Commis-} sion with an enforcement agency that

\footnotetext{
${ }^{13} I d$.

${ }^{14}$ Id. at 660 n.44 (citations omitted).

15 See generally id. at 644-54 (discussion of major developments in federal campaign finance law over the twentieth century); Anthony Corrado, A History of Federal Campaign Finance Law, in Campaign Finance Reform: A Sourcebook (Anthony Corrado, Thomas E. Mann, Daniel Ortiz, Trevor Potter \& Frank Sorrauf eds., 1997).

${ }^{16} \mathrm{Id}$. at 706.
} 
will actually enforce the law. No campaign finance law is going to live up to its full potential until we have an agency that will enforce the rules as Congress intended. The FEC has demonstrated time and again that it is not such an agency. In the regulations it writes, in the advisory opinions it renders, and in the way it conducts its enforcement functions, the Commission has simply failed to do its job. The sole agency charged with serving as the election watchdog has proven itself to be, in the words of the Washington Post, "The Dog That Never Barks."17

As a blue-ribbon task force concluded just last year, the FEC "is a classic example of a 'captured' agency-one that serves the interests of the community it is supposed to regulate. In this instance, the 'regulated community' comprises those elected officials and party leaders who have the power to appoint the FEC commissioners in the first instance." 18 If more evidence were required than the agency's creation of the soft money system to prove that the Commission has failed, one need only consider the agency's new rules to implement BCRA. At every turn, the Commission fought in 2002 to narrow and undermine the law that Congress passed after years of consideration and debate. Rather than looking to congressional intent to inform its rulemaking, the Commission often flatly rejected the advice of the law's principal congressional sponsors, and on a number of occasions, that of its own general counsel. The FEC's BCRA rules were so plainly contrary to congressional intent that they are now the subject of a lawsuit by congressional sponsors of the new law, who are urging that these rules should be thrown out as arbitrary and contrary to law. ${ }^{19}$

The Commission is simply structured to fail. The agency has deadlocked time and again on 3-3 votes, along party lines. ${ }^{20}$ And the process of nominating commissioners has become the stuff of farce. By long tradition, the President's nomination is merely a rubber stamp on selections made by the party campaign committees and legislative leadership. In turn, those appointed to serve on the Commission have all too often used their position to protect their party's interests, rather than enforce the laws as written. In recent years, the parties have even nominated individuals who oppose as unconstitutional the very idea of campaign finance regulation. The current chairman of the Commission is someone who was appointed largely because of his rigid opposition to campaign regulation, and who, while on the Commission, has continued a public campaign against the new Reform Act. And this year, the Democratic leadership has thus far declined to support for reappointment an experienced commissioner who has shown courage and skill in arguing for strict enforcement of the old and new campaign finance laws, opting instead to urge the president to appoint a lawyer who signed pleadings opposing BCRA on behalf of his clients.

Along with my colleagues Senator Russell Feingold (D-Wis.) and Representatives Christopher Shays (R-Ct.) and Marty Meehan (D-Mass.), I have introduced legislation that would eliminate this broken agency and replace it with one that has the structure and political will necessary to enforce campaign finance law properly. ${ }^{21}$ The bill would start anew with a Federal Election Administration (FEA) with three commissioners appointed by the President and confirmed by the Senate, with one chair and two other members from opposite political parties. We believe that this odd-numbered structure, with a strong

17 See Editorial, The Dog That Never Barks, WAsH. Post, Nov. 26, 2002, at A28.

18 "No Bark, No Bite, No Point" at 15, Project FEC (Fred Wertheimer and Don Simon, eds.) 2002. The report can be found at www.democracy21.org.

19 See Shays v. FEC, No. 02-CV-1984(D.D.C. Jan. 21, 2003).

${ }^{20}$ Defenders of the status quo argue that the FEC deadlocks in only a small percentage of its cases. The deadlocked cases, however, are almost always the most important in terms of the legal issues at stake, and often the most politically contentious as well. See "No Bark, No Bite, No Point," supra note 18, at 9-11.

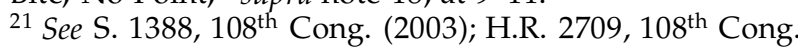
(2003). 
chair, will force Congress and the President to pay more attention to the appointments process and result in the selection of more impartial and effective commissioners. Ideally, the President would appoint a nonpartisan panel of outside advisors to recommend names for appointment to the Commission. Enforcement proceedings would be conducted by objective administrative law judges to reduce the role of politics in these critical proceedings, and any final determination made by the judges could be appealed to the FEA for final action, subject to judicial review. Our proposal would also give the FEA enhanced authority to impose penalties, issue cease-and-desist orders and conduct audits and field examinations of campaign committees.

- Reduce the influence of large donations, promote competitiveness and encourage greater citizen participation by fixing the presidential public financing system and offering free air time to candidates. Our work to protect and enhance the campaign finance laws has long focused on the central problem of corruption. But legislative efforts need desperately to address a more subtle dynamic in modern campaigns that continues to erode citizens' faith in their government.

The skyrocketing cost of campaignslargely driven by the cost of broadcast advertising time-now causes politicians to focus on large donors to their campaigns. And it is, in turn, those candidates who effectively focus on large donors and raise the most cash who are often best able to mount serious campaigns, particularly at the presidential level. The result is both the appearance and reality that candidates are largely disengaged from those citizens who can only give small amounts-or nothing at all. This contributes to the sense of average Americans that their voices are drowned out by wealthier contributors and special interests. That sense of disempowerment, in turn, has steadily eroded citizens' incentive to participate in the civic life of our nation.

The Supreme Court has held that Congress cannot constitutionally cap the amounts candidates spend on their own races. But Congress can do much more to build a set of incentives that allow candidates to focus on low-dollar donors and non-contributors as they run for office.

First, the system of presidential public financing must be repaired. Since 1976, the system has had widespread support and served our nation well. The one-to-one public match of every private dollar raised up to $\$ 250$ enhanced the value of these smaller donations and allowed politicians to focus more on those donors who can't "max out" at $\$ 2,000$ per election.

But now, the front-loaded primary season forces participating candidates to reach spending limits early, and leaves those who survive virtually penniless through the summer conventions. In the current cycle, if the Democratic primary winner has accepted public funding and is thus subject to the spending limit, he faces a potentially severe political consequence: being battered every day prior to the convention on the airwaves by an incumbent president who has no primary challenger, has rejected primary public financing, and is continuing to raise substantial sums for his "primary" campaign. As a result, there are considerable incentives for some candidates to opt out of public financing. And with the higher individual contribution limits under BCRA, the one-to-one match on $\$ 250$ donations is considerably less valuable than it once was. ${ }^{22}$

We need to attack the problem on several fronts to fix the system. We should increase the public match to four-to-one on the first $\$ 250$ of every private contribution. That will increase the value of smaller contributions enough to allow candidates to focus on lower-dollar donors, rather than focusing almost exclusively on wealthy donors. Candidates should have to opt into the system for both the primary and

\footnotetext{
22 For an excellent history and analysis of the problems facing the presidential primary public funding system, see "Participation, Competition, Engagement: How to Revive and Improve Public Funding for Presidential Nomination Politics," Campaign Finance Institute, 2003.
} 
the general election in order to receive funds. We should also provide incentives for candidates to participate by increasing the spending limits for participating candidates if non-participating candidates decide to spend beyond the statutory caps. We also need to raise the primary spending limits to more realistic levels, and fix the funding mechanism by increasing the amount of their tax payments that voters can allocate to the system by checking off a box on their tax return. ${ }^{23}$

Finally, we need to address the factor that drives the rising cost of campaigns more than any other: television and radio broadcast advertisements. Political advertisements are indispensable to modern campaigns, and fundraising is largely about raising the cash to pay for them. At the same time, broadcasters regularly ignore or short-change the responsibility they bear under the Communications Act of 1934 to broadcast programs in the public interest.

Along with Senators Russell Feingold and Richard Durbin (D-Ill.), I have introduced legislation that would seek to reclaim the public airwaves and provide public incentives for candidates to limit their fundraising. ${ }^{24}$ The legislation would require that $T V$ and radio stations offer a few hours of civic broadcasting every week around election time. It would also implement a voucher system in which low-dollar contributions to candidates would be matched with vouchers with which candidates could buy advertising. This could be funded by a small spectrum use fee on broadcast stations.

These are just a few of the steps that, based on the simple principles in the Supreme Court's decision in McConnell, Congress can and should take to improve our system of campaign finance. Having taken great steps forward in reducing the corruption caused by large contributions, we need to open the door to greater citizen participation in our election system, including more small donor financing of political campaigns. As this next phase begins, we go forward with the path well-laid, the wind at our backs, and the price of past failures abundantly clear.

E-mail: mviray@campaignlegalcenter.org

${ }^{23}$ The check-off does not increase voters' tax liability but rather allocates a portion of their tax payments to the presidential public financing system.

${ }^{24}$ See S. 1497, Our Democracy, Our Airwaves Act, $108^{\text {th }}$ Cong. (2003). 